\title{
Regulatory polymorphisms in the bovine Ankyrin 1 gene promoter are associated with tenderness and intramuscular fat content
}

\author{
Ozlem Aslan ${ }^{1,2}$, Torres Sweeney ${ }^{2}$, Anne Maria Mullen, Ruth M Hamill ${ }^{1 *}$
}

\begin{abstract}
Background: Recent QTL and gene expression studies have highlighted ankyrins as positional and functional candidate genes for meat quality. Our objective was to characterise the promoter region of the bovine ankyrin 1 gene and to test polymorphisms for association with sensory and technological meat quality measures.

Results: Seven novel promoter SNPs were identified in a $1.11 \mathrm{~kb}$ region of the ankyrin 1 promoter in Angus, Charolais and Limousin bulls ( $n=15$ per breed) as well as 141 crossbred beef animals for which meat quality data was available. Eighteen haplotypes were inferred with significant breed variation in haplotype frequencies. The five most frequent SNPs and the four most frequent haplotypes were subsequently tested for association with sensory and technological measures of meat quality in the crossbred population. SNP1, SNP3 and SNP4 (which were subsequently designated regulatory SNPs) and SNP5 were associated with traits that contribute to sensorial and technological measurements of tenderness and texture; Haplotype 1 and haplotype 4 were oppositely correlated with traits contributing to tenderness $(P<0.05)$. While no single SNP was associated with intramuscular fat (IMF), a clear association with increased IMF and juiciness was observed for haplotype 2.

Conclusion: The conclusion from this study is that alleles defining haplotypes 2 and 4 could usefully contribute to marker SNP panels used to select individuals with improved IMF/juiciness or tenderness in a genome-assisted selection framework.
\end{abstract}

\section{Background}

Ankyrins are structural proteins forming a fundamental component of the cytoskeleton. They are a family of proteins that link the integral membrane proteins to the underlying spectrin-actin cytoskeleton, which in muscle forms a highly complex network of inter-myofibril connections as well as connections between myofibrils and the sarcolemma $[1,2]$ and the sarcoplasmic reticulum [2-5]. Ankyrin contains a regulatory domain which is sensitive to proteolysis [6]. Ankyrins are a known target of the calpains [7-9] which are a family of endogenous cysteine proteases that have been shown to be fundamental to the post-mortem proteolysis of myofibrillar proteins and cytoskeletal proteins and consequent meat tenderisation [10-14]. Degradation of key myofibrillar proteins and the cytoskeleton results in the linkages

\footnotetext{
* Correspondence: ruth.hamill@teagasc.ie

${ }^{1}$ Teagasc, Food Research Centre, Ashtown, Dublin 15, Ireland

Full list of author information is available at the end of the article
}

between myofibrils being broken, thus meat becomes tender [15]. The proteolysis of ankyrin is anticipated to cause a serious effect on cellular integrity [16] with potential consequences for sensory and technological characteristics of meat.

Recent research has highlighted $A N K 1$ as a positional and functional candidate gene for meat quality in foodproducing animals. The bovine ankyrin 1 gene has been mapped close to a QTL for fat associated traits, including marbling in meat [17-19] on bovine chromosome 27. In parallel, expression of the porcine ankyrin 1 gene has been associated with a number of meat quality traits, including tenderness, intramuscular fat level (IMF) and water-binding capacity [20].

Genetic polymorphism in the promoter region is one of the mechanisms known to influence variability in the expression of a gene, with associated consequences for the phenotypic diversity of a population [21-25]. Here, the objective of this study was to characterise single nucleotide
C Biomed Central

(c) 2010 Aslan et al; licensee BioMed Central Ltd. This is an Open Access article distributed under the terms of the Creative Commons Attribution License (http://creativecommons.org/licenses/by/2.0), which permits unrestricted use, distribution, and reproduction in any medium, provided the original work is properly cited. 
polymorphisms in a $1.11 \mathrm{~kb}$ region of the bovine ANK1 promoter region and to test for association with technological and sensory parameters of meat quality traits.

\section{Results}

\section{Characterisation of a novel muscle transcript of the} bovine ankyrin 1 gene

After 5' RACE-PCR, two ANK1 transcripts differing in size by approximately 350 bp were observed (Figure 1 ). The smaller fragment was consistent with previously published sequence [Bos taurus ankyrin 1 mRNA, partial CDs; GenBank: AF222766.1]. The larger transcript was novel and hence was cloned and sequenced (Figure 2). The novel mRNA sequence was submitted to the EMBL database with accession number [FR717674].

$341 \mathrm{bp}$ of the larger transcript was not annotated in the NCBI database and hence was considered a novel mRNA sequence. The novel transcription start site (TSS) was upstream of the previously predicted TSS for this gene $(39,124,124)$ reported in [AF222766.1] (btau_4.0). The genomic location of the novel mRNA sequence was immediately adjacent to the known genomic DNA sequence of exon 1. An ATG codon was located 17-19 bp downstream of the novel TSS. The sequence around this new ATG codon matches important elements of the Kozak consensus sequence, including a $\mathrm{G}$ at +4 , and $\mathrm{CC}$ at -2 to -1 . In addition, three putative TATA boxes were located $110 \mathrm{bp}, 764 \mathrm{bp}$ and 774 bp upstream of the TSS: TTATTAA, TATTTTTA, and TTATA respectively (Figure 3 ). The predicted initiator methionine was in frame with the previously identified start codon in exon 1. A stop codon was present at position 191-193 bp.

\section{Promoter SNP discovery}

Resequencing of $1.11 \mathrm{~kb}$ upstream of the novel bovine ANK1 novel transcript TSS revealed seven novel

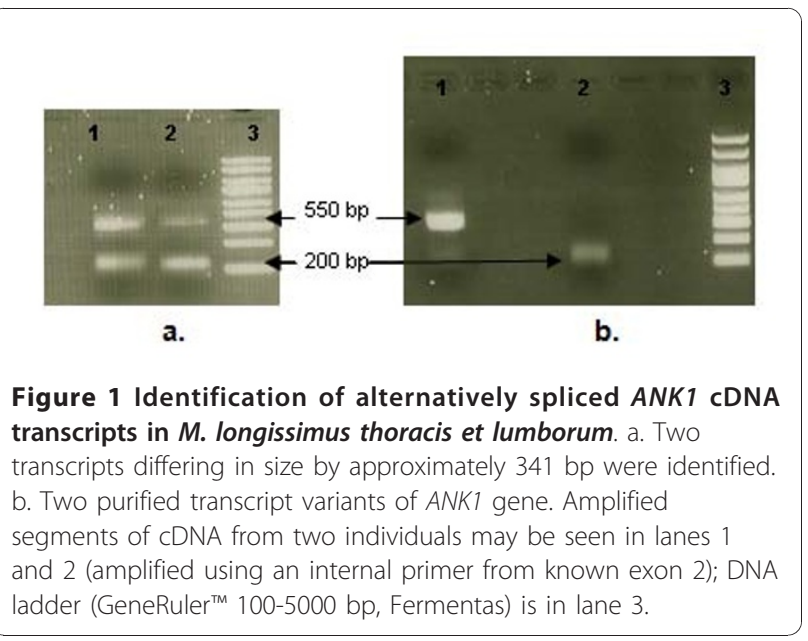

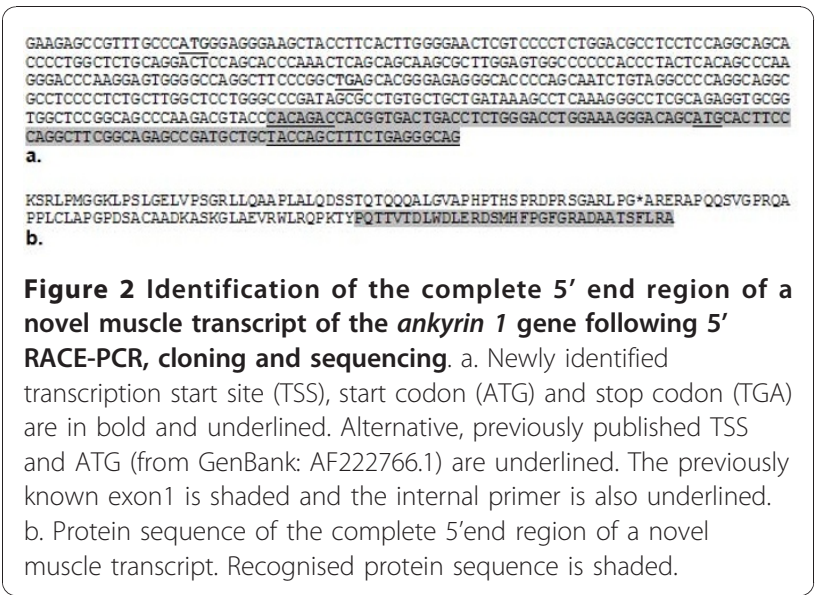

promoter SNPs located as follows, relative to the transcription start site: SNP1 (C:T) at position -24, SNP2 (C:T) at position -307, SNP3 (G:A) at position -672, SNP4 (C:G) at position -687, SNP5 (C:T) at position -733 and SNP6 (C:T) at position -944, and SNP7 (A:C) at position -961 (Table 1 and 2). SNPs 1-5 were observed in all the populations examined and genotype frequencies were in agreement with Hardy-Weinberg equilibrium (Table 2).

Allele and haplotype frequencies were determined in two European breeds (Charolais and Limousin) and one British breed (Angus), which are all represented in the Irish herd. SNP6 was monomorphic in Aberdeen Angus and Limousin breeds, while SNP7 was monomorphic in the Aberdeen Angus breed (Table 1, 2). However, only this latter SNP (SNP7) displayed significant divergence in allele frequency between Limousin and Aberdeen Angus $(P<0.001)$ and between Charolais and Aberdeen Angus $(P=0.042)$. SNP1-5 had minor allele frequencies greater than $10 \%$ in all populations examined, with the exception of SNP4, which had a minor allele frequency of $3.3 \%$ in the Limousin breed (Table 1).

\section{Transcriptional Effects of regulatory SNPs in the bovine ANK1 promoter region}

If a transcription factor binding site (TFBS) of a gene is polymorphic in a population this can lead to variation in the level or timing of gene expression [26-28]. In this study, seven novel promoter SNPs were analysed in silico to determine if they created or abolished putative transcription factor binding motifs and hence could be described as regulatory SNPs (rSNPs). rSNPs 1, 3, 4 and 7 were located within putative transcription factor binding motifs and either created or abolished putative TFBS as illustrated in Table 3. While three different TFBS predictor tools were used in this study, only five motif changes were supported by more than one prediction tool: 


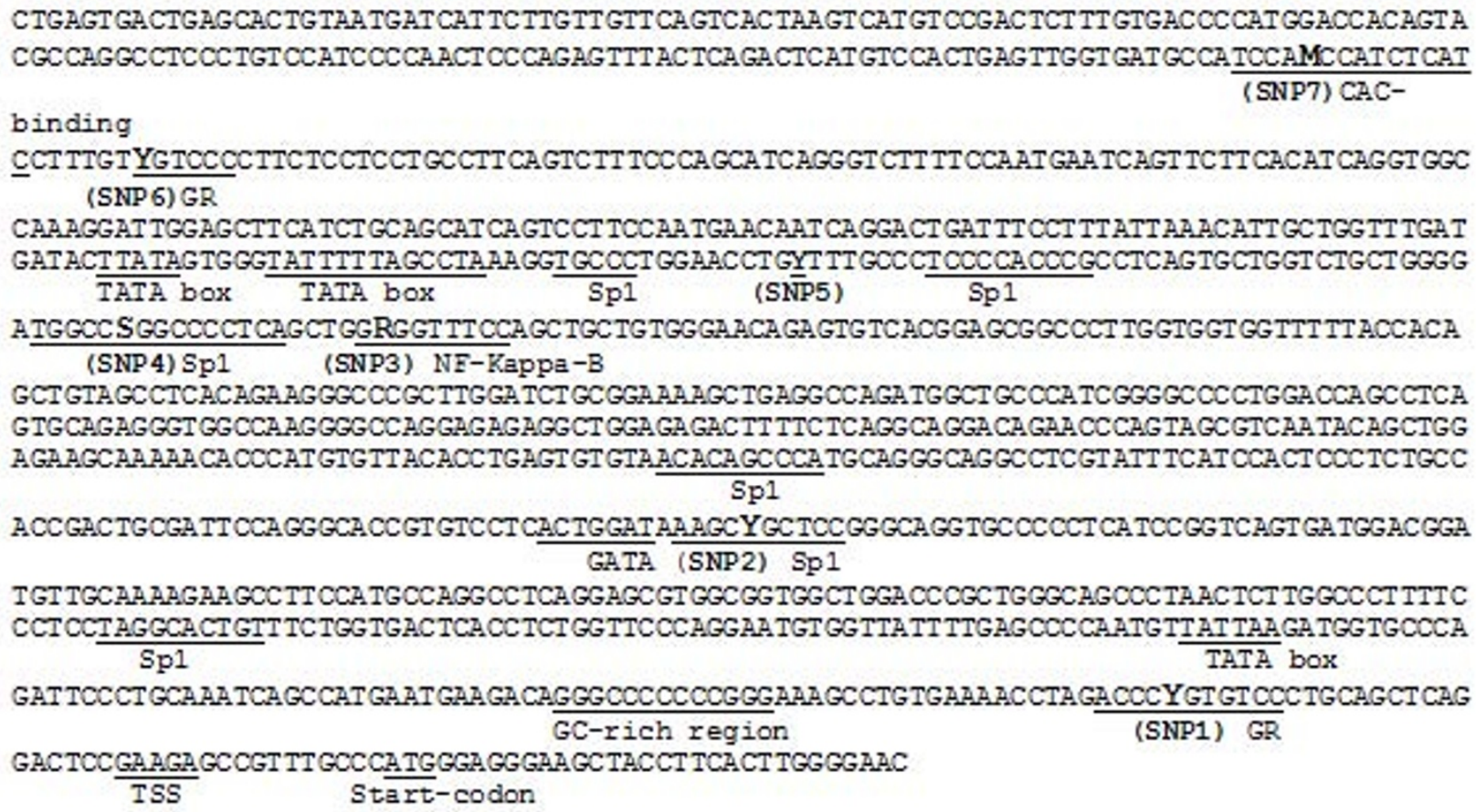

Figure 3 Nucleotide sequence of the regulatory region $1.11 \mathrm{~kb}$ upstream of the novel bovine ANK1 transcription start site. Some of the putative transcription factor binding sites, the TSS, and the predicted start codon are indicated.

\section{rSNP1}

Glucocorticoid receptor- The presence of the minor $\mathrm{T}$ allele at rSNP1 led to the creation of a putative glucocorticoid receptor transcription factor binding site, which was not present with the alternate $C$ allele.

\section{rSNP4-Sp1}

The presence of the minor G allele at rSNP4 abolishes a putative Sp1 transcription factor binding site, that was present with the alternate.

rSNP4-delta factor (YY1)

The presence of the minor $G$ allele created a delta factor transcription factor binding site, that was not present with the alternate.

\section{rSNP7-CAC-binding}

The presence of the minor $\mathrm{C}$ allele at rSNP7 creates a putative CAC-binding transcription factor binding site, which was not present with the alternate A.

\section{Haplotype construction}

Linkage disequilibria plots are presented in Figure 4a-d. Pair-wise $r^{2}$ values were close to 1 for rSNP1, 3 and 5, indicating they were in high linkage disequilibrium with each other in the four populations. Haplotypes are defined as a combination of SNP alleles closely linked on the same chromosome. Haplotype-based methods can provide higher power to asses the complex

Table 1 Positions and minor allele frequencies of the rSNPs observed in crossbred cattle $(n=141)$ and Angus $(n=15)$, Charolais $(n=15)$ and Limousin $(n=15)$ breeds

\begin{tabular}{|c|c|c|c|c|c|c|c|}
\hline SNP & SNP position relative to TSS & dbSNP submitter snp (ss) no & Alternate alleles $(1 / 2)$ & Minor & Allele Fre & quency & \\
\hline & & & & Crossbred animals & ANG & CHAR & LIM \\
\hline SNP1 & -24 & 275515731 & $\mathrm{C} / \mathrm{T}$ & $0.245(\mathrm{~T})$ & $0.100(\mathrm{~T})$ & $0.233(\mathrm{~T})$ & $0.300(\mathrm{~T})$ \\
\hline SNP2 & -307 & 275515732 & $\mathrm{C} / \mathrm{T}$ & $0.436(C)$ & $0.400(\mathrm{~T})$ & $0.433(C)$ & $0.500(\mathrm{~T})$ \\
\hline SNP3 & -672 & 275515733 & $A / G$ & $0.227(\mathrm{~A})$ & $0.100(A)$ & $0.233(A)$ & $0.333(A)$ \\
\hline SNP4 & -687 & 275515734 & $C / G$ & $0.142(\mathrm{G})$ & $0.100(\mathrm{G})$ & $0.167(\mathrm{G})$ & $0.033(\mathrm{G})$ \\
\hline SNP5 & -733 & 275515735 & $\mathrm{C} / \mathrm{T}$ & $0.241(\mathrm{~T})$ & $0.100(\mathrm{~T})$ & $0.233(\mathrm{~T})$ & $0.300(\mathrm{~T})$ \\
\hline SNP6 & -944 & 275515736 & $\mathrm{C} / \mathrm{T}$ & $0.082(\mathrm{~T})$ & $0.0(\mathrm{~T})$ & $0.067(\mathrm{~T})$ & $0.0(\mathrm{~T})$ \\
\hline SNP7 & -961 & 275515737 & $\mathrm{~A} / \mathrm{C}$ & $0.014(C)$ & $0.0(A)$ & $0.167(A)$ & $0.267(A)$ \\
\hline
\end{tabular}

ANG: Aberdeen Angus, CHAR: Charolais, LIM: Limousin 
Table 2 Observed and expected heterozygosities of the rSNPs in crossbred animals and Angus, Charolais and Limousin breeds

\begin{tabular}{|c|c|c|c|c|c|c|c|c|c|c|}
\hline \multirow[t]{2}{*}{ SNP } & \multirow[t]{2}{*}{$\begin{array}{l}\text { SNP position } \\
\text { relative to TSS }\end{array}$} & \multirow[t]{2}{*}{$\begin{array}{c}\text { Alternate alleles } \\
(1 / 2)\end{array}$} & \multicolumn{2}{|c|}{$\begin{array}{l}\text { Crossbred animals } \\
\quad(n=141)\end{array}$} & \multicolumn{2}{|c|}{$\begin{array}{c}\text { ANG } \\
(n=15)\end{array}$} & \multicolumn{2}{|c|}{$\begin{array}{c}\text { CHAR } \\
(n=15)\end{array}$} & \multicolumn{2}{|c|}{$\begin{array}{c}\text { LIM } \\
(n=15)\end{array}$} \\
\hline & & & $H_{O}$ & $H_{E}$ & $H_{O}$ & $H_{E}$ & $H_{O}$ & $H_{E}$ & $H_{O}$ & $H_{E}$ \\
\hline SNP1 & -24 & $\mathrm{C} / \mathrm{T}$ & 0.39 & 0.37 & 0.2 & 0.18 & 0.333 & 0.358 & 0.47 & 0.42 \\
\hline SNP2 & -307 & $\mathrm{C} / \mathrm{T}$ & 0.489 & 0.492 & 0.533 & 0.48 & 0.333 & 0.491 & 0.6 & 0.5 \\
\hline SNP3 & -672 & $\mathrm{~A} / \mathrm{G}$ & 0.355 & 0.351 & 0.2 & 0.18 & 0.333 & 0.358 & 0.4 & 0.444 \\
\hline SNP4 & -687 & $C / G$ & 0.213 & 0.243 & 0.2 & 0.18 & 0.2 & 0.278 & 0.07 & 0.064 \\
\hline SNP5 & -733 & $\mathrm{C} / \mathrm{T}$ & 0.397 & 0.366 & 0.2 & 0.18 & 0.333 & 0.358 & 0.47 & 0.42 \\
\hline SNP6 & -944 & $\mathrm{C} / \mathrm{T}$ & 0.163 & 0.15 & 0 & 0 & 0.133 & 0.124 & 0 & 0 \\
\hline SNP7 & -961 & $\mathrm{~A} / \mathrm{C}$ & 0.028 & 0.028 & 0 & 0 & 0.333 & 0.278 & 0.53 & 0.391 \\
\hline
\end{tabular}

ANG: Aberdeen Angus, CHAR: Charolais, LIM: Limousin $H_{O}$ : Observed heterozygosity, $H_{E}$ : Expected heterozygosity

relationship between genetic variation and phenotypes, compared with methods based on single SNP analysis $[29,30]$.

Eighteen potential haplotypes were inferred in the study. Four inferred haplotypes had allele frequencies greater than $10 \%$ (Table 4) in the crossbred animals group. The top three haplotypes were HAP2 (CTGCCCA), HAP3 (TCACTCA) and HAP4 (CCGCCCA) with frequencies of $0.344,0.185$ and 0.177 respectively. These were also the top three haplotypes in both Charolais and Limousin breeds. In the Aberdeen Angus breed, the main haplotypes were HAP1 (CTGGCCA), HAP2 (CTGCCCA) and HAP4 (CCGCCCA) which had frequencies of $0.10,0.266$ and 0.534 respectively. Phylogenetic reconstruction indicated that HAP1 and HAP2 were the most closely related haplotypes, followed by HAP4. HAP3 was most distant (Figure 5).

\section{Association analysis \\ Single SNP association}

Associations between the rSNPs and meat quality traits (technological and sensory) are reported in Table 5. Least-squares means for meat quality traits for each genotype are also presented in Table 5. Overall, four of the five single SNPs tested showed association with at least one meat quality trait. These comprised of 17 significant associations $(P<0.05)$ and 6 tendencies towards association $(P<0.1)$ in total. Three SNPs which were in strong LD with each other (rSNP1, rSNP3 and rSNP5) were associated with sensory tenderness in LTL and/or SM muscle. rSNP1 and rSNP5 were also associated with an objective measure of tenderness (Warner-Bratzler shear force) in both LTL and SM muscles, while rSNP3 was associated with shear force in LTL. rSNP1 and rSNP5 were also associated with sensory texture in both LTL and SM muscles, whereas rSNP3 and rSNP4 were associated with texture in LTL and SM muscle, respectively.

\section{Haplotype association}

A number of significant associations were found between individual $A N K 1$ promoter haplotypes and aspects of meat quality. Least squares means, associated $P$-values and Tukey-Kramer contrasts are presented in Table 6. Each of the four most common haplotypes was associated with at least one aspect of sensory or technological quality:

HAP1 Homozygous HAP1 individuals had reduced texture scores in SM $(P=0.0012)$ and increased firmness scores in LTL muscle $(P=0.0176)$, compared to individuals with no copy of this haplotype.

HAP2 The most common haplotype, HAP2, was associated with IMF content in both LTL and SM muscle ( $P=0.0276$ and $P=0.0275$, respectively). Homozygous HAP2 individuals had almost twice as much IMF content $(1.95 \%)$ in SM, compared with those that had no copies of the haplotype (1.06\%). In LTL muscle, there was also an increase in IMF \% with haplotype 2. IMF levels were higher in LTL muscle, compared with SM but the trend was the same - Individuals with two copies had $3.24 \%$ fat compared with $1.99 \%$ for those with zero copies. For both SM and LTL, individuals with one copy of the haplotype had intermediate levels of fat. This association was supported by a tendency towards increased juiciness in SM muscle $(P=0.077)$ of HAP2, as fat influences juiciness [31,32].

HAP3 This haplotype was associated with texture in LTL $(P=0.0070)$ and tenderness score in SM muscle $(P=$ 0.0317).

HAP4 A significant observation was that homozygous or heterozygous individuals for HAP4 had increased tenderness scores, decreased firmness and lower shear force values in LTL muscle compared to non-carriers. In addition, non-carrier animals were $10 \%$ firmer $(5.34 \pm$ $0.09)$ than for either homozygous or heterozygous carriers $(5.02 \pm 0.27$ and $5.00 \pm 0.12$, respectively). Individuals with one copy of HAP4 had lower texture score compared to those without this haplotype. 
Table 3 Selected transcription factor binding motifs in the ANK1 promoter predicted by TESS, TRANSFAC and Matinspector prediction tools

\begin{tabular}{|c|c|c|c|c|c|c|}
\hline *SNPs & $\begin{array}{l}\text { Putative } \\
\text { Transcription Factors }\end{array}$ & $\begin{array}{l}\text { Prediction } \\
\text { tool }\end{array}$ & $\begin{array}{l}\text { Created } \\
\text { with }\end{array}$ & $\begin{array}{l}\text { Recognition } \\
\text { Sequence }\end{array}$ & Start & End \\
\hline \multirow[t]{4}{*}{ rSNP1 (-24), C/T } & GAL4 & TESS & $C$ & CCCC & -27 & -24 \\
\hline & E-box binding factors & Matlnspector & $\mathrm{C}$ & AGACCCCGTGTCC & -36 & -27 \\
\hline & USF & TRANSFAC MatInspector & C & CCCCGTGTCC & -27 & -18 \\
\hline & $\overline{G R}$ & $\begin{array}{l}\text { Matlnspector } \\
\text { TRANSFAC } \\
\text { TESS }\end{array}$ & $\mathrm{T}$ & $\begin{array}{l}\text { CAGGGACACAGGGTCTAGG* } \\
\text { ACCCTGTGTCC } \\
\underline{\text { TGTGTC }}\end{array}$ & $\begin{array}{l}-15 \\
-28 \\
-24 \\
\end{array}$ & $\begin{array}{l}-33 \\
-18 \\
-19 \\
\end{array}$ \\
\hline \multirow[t]{2}{*}{ pSNP2 (-307), C/T } & $\mathrm{T}-\mathrm{Ag}$ & TESS & C & GCCGC & -309 & -305 \\
\hline & Sp1 & TRANSFAC & $\mathrm{T}$ & AAGCIGCTCC & -311 & -302 \\
\hline \multirow[t]{5}{*}{ rSNP3 (-672), A/G } & Sp1 & $\begin{array}{l}\text { TRANSFAC } \\
\text { TESS }\end{array}$ & A & $\begin{array}{l}\text { GCCAGGCCCCTCAGC } \\
\text { AGGCCCC }\end{array}$ & $\begin{array}{l}-675 \\
-672\end{array}$ & $\begin{array}{l}-661 \\
-666\end{array}$ \\
\hline & $\mathrm{NF}-1$ & TESS & A & TGGA & -675 & -672 \\
\hline & NF-Kappa-B & TRANSFAC & $G$ & GGGGGTTCC & -674 & -665 \\
\hline & $\overline{\text { GAL4 }}$ & TESS & G & GGGG & -674 & -671 \\
\hline & MIG1 & TESS & G & CTGGGG & -676 & -671 \\
\hline \multirow[t]{10}{*}{ rSNP4 (-687), C/G } & Sp1 & $\begin{array}{l}\text { TRANSFAC } \\
\text { TESS }\end{array}$ & $C$ & $\begin{array}{l}\text { ATGGCCCGGCCCCT } \\
\text { GCCCGGCCCC }\end{array}$ & -666 & -669 \\
\hline & & & & & -690 & -681 \\
\hline & Oct-01 & TRANSFAC & $C$ & GCCCGGCCCC & -690 & -681 \\
\hline & $\overline{N F-1}$ & TRANSFAC & C & TGGCCGGGCC & -691 & -682 \\
\hline & Sp1 & TRANSFAC & G & GGCCGGGCCCCTCA & -691 & -678 \\
\hline & $\overline{Y Y 1}$ & TRANSFAC TESS & G & GATGGCCGG & -694 & -686 \\
\hline & GCF & TESS & G & SCGSSSC & -689 & -683 \\
\hline & Krueppel like & Matlnspector & G & CTGAGGGGCCGGGCCAT* & -677 & -693 \\
\hline & Nuclear factor Kappa B/C-Rel & Matlnspector & G & TGGGGATGGCCCG & -698 & -686 \\
\hline & GC-box factors SP1/GC & Matlnspector & G & GAGGGGCCGGGCCAT* & -679 & -693 \\
\hline \multirow[t]{5}{*}{ pSNP5 (-733), C/T } & Oct-01 & TRANSFAC & C & TGCITTGCCC & -737 & -728 \\
\hline & $\overline{\text { LVC }}$ & TESS & C & CCTGC & -737 & -733 \\
\hline & GCF & TESS & C & GSSSCGS & -737 & -731 \\
\hline & $S n$ & TESS & $\mathrm{T}$ & ACCTGIT & -738 & -732 \\
\hline & Grainyhead-like factors & Matlnspector & $\mathrm{T}$ & GGAACCTGIITTG & -741 & -729 \\
\hline \multirow[t]{3}{*}{ pSNP6 (944), C/T } & Oct-01 & TRANSFAC & C & CTGE_TITGCC & -947 & -938 \\
\hline & Glucocorticoid receptor & TESS & $\mathrm{T}$ & $\begin{array}{l}\text { TGTTGT } \\
\text { IGTCCCC }\end{array}$ & $\begin{array}{l}-947 \\
-944\end{array}$ & $\begin{array}{l}-942 \\
-939\end{array}$ \\
\hline & Krueppel like factors & Matlnspector & $\mathrm{T}$ & CAACAAAGGATGAGATG* & -943 & -959 \\
\hline rSNP7 (961), A/C & CAC-binding & $\begin{array}{l}\text { TESS } \\
\text { MatInspector }\end{array}$ & C & $\begin{array}{l}\text { CCACC } \\
\text { TCCĀCCCATCTCATC }\end{array}$ & $\begin{array}{l}-964 \\
-965\end{array}$ & $\begin{array}{l}-960 \\
-651\end{array}$ \\
\hline
\end{tabular}

*Only the SNPs that create putative transcription factor binding sites were listed. *Minus strand. SNP positions in the recognition sequence are underlined.

HAP5 This haplotype was associated with texture in SM muscle $(P=0.0445)$. Heterozygous individuals had increased texture score compared to those with no copy of this haplotype.

\section{Discussion}

Here, we have identified a new transcript variant of the bovine ankyrin 1 gene in muscle. Seven novel SNPs were identified in the promoter region and several associations between the promoter SNPs and haplotypes and meat quality traits were observed. After correction for multiple testing, associations between rSNPs 1 and 4, and haplotype 2 and meat quality were significant.

We have shown that a novel variant of the ankyrin 1 gene is present in muscle. This variant is longer than previously reported variants $(\mathrm{NCBI})$ and increases the overall gene length by $341 \mathrm{bp}$ in the 5 ' direction. The identification of alternative transcripts of bovine $A N K 1$ is not surprising. Indeed, mammalian genomes express three ankyrin proteins, which are encoded by three 


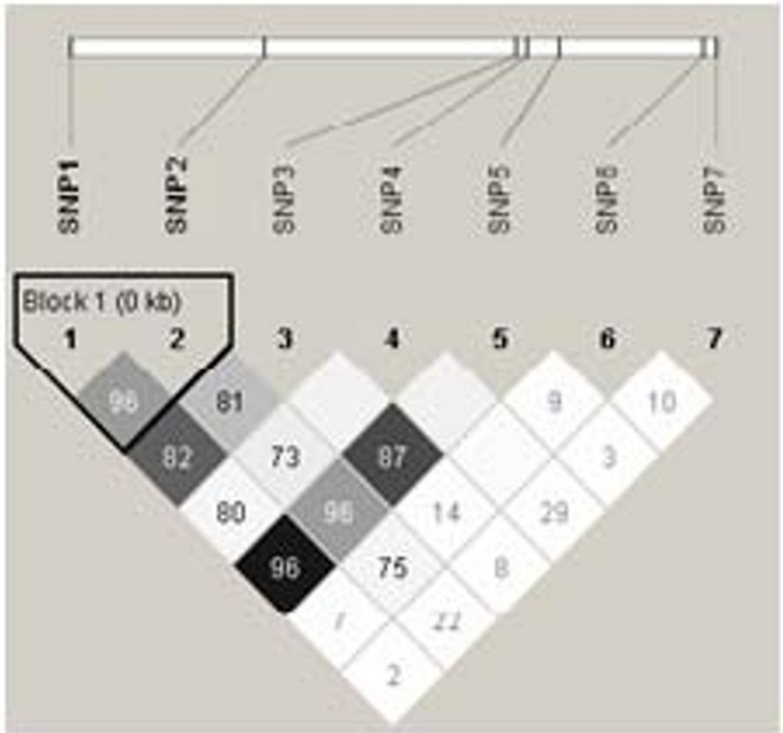

a.

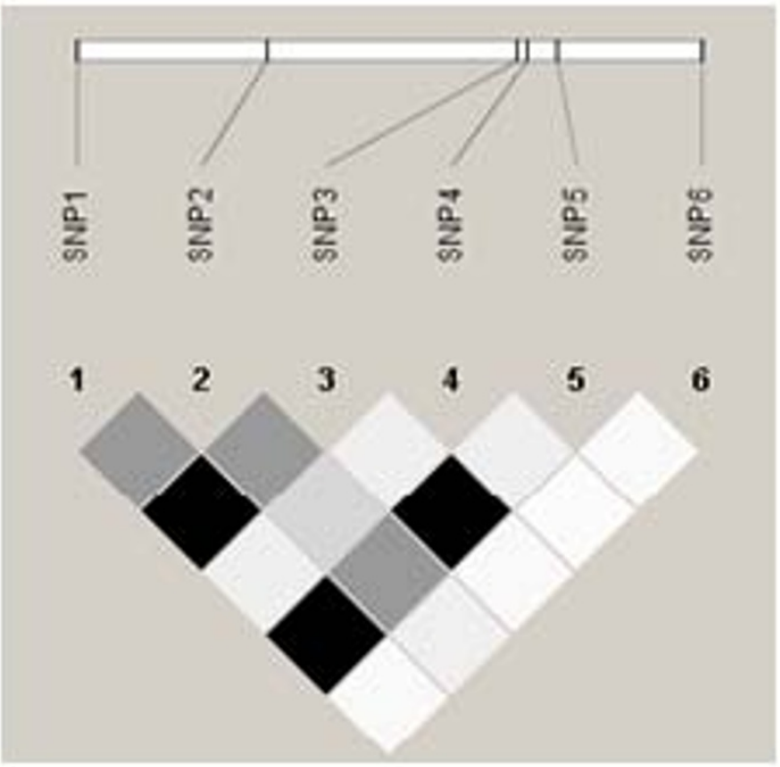

c.

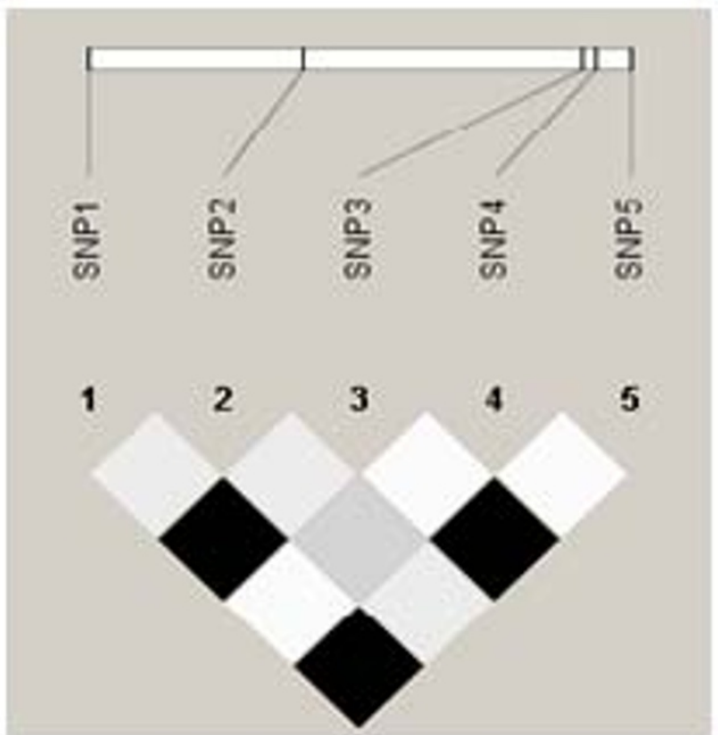

b.

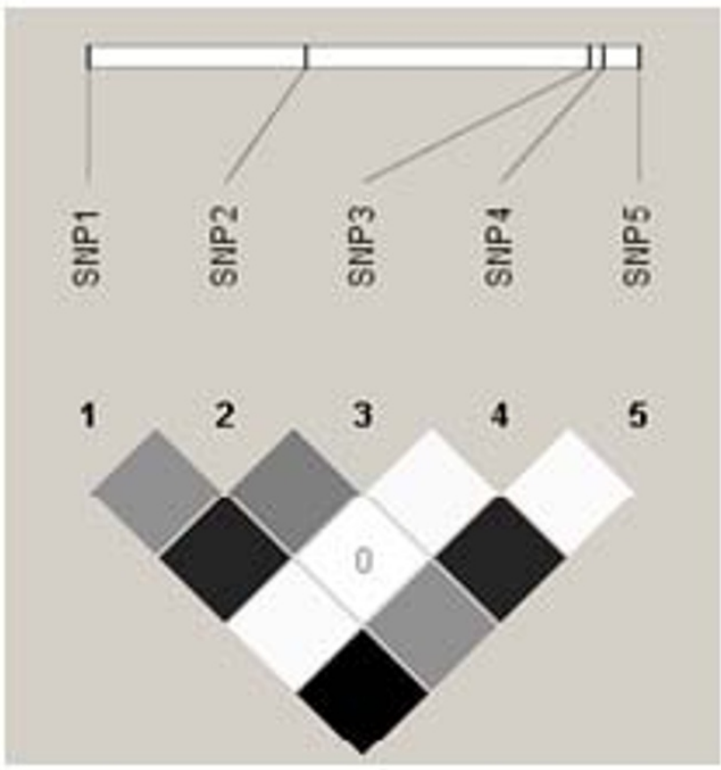

d.

Figure 4 Pairwise linkage disequilibrium plots indicating $r^{2}$ values for 7 SNP in the regulatory region of the examined populations. a. Crossbred samples $(n=141)$, b. Aberdeen Angus, c. Charolais, d. Limousin $(n=15$ for each breed). Dark grey and black squares indicate statistically significant (LOD > 2) allelic association between a pair of SNPs; darker greys indicate higher values of $\boldsymbol{r}^{2}$, up to a maximum of 1 (black). White and light grey squares indicate no statistically significant evidence of LD.

separate genes (ANK1-3) [33-35]. In bovine, $A N K 2$ is located on chromosome $6(13,335,381$ - 13,706,921; btau_4.0) and $A N K 3$ is located on chromosome 28 $(14,417,416$ - 14,535,840; btau_4.0). Unlike ANK1, neither map close to QTL for meat quality traits. However, ANK2 maps close to several QTL for carcass yield traits including longissimus muscle area [18] and back fat EBV [36,37]. The functional and molecular diversity of the ankyrin family is a result of differential expression of these three independent genes and their widely alternatively spliced variants, some missing large segments that include whole functional domains [38-42]. It has been reported that ankyrin 1 has the most limited pattern of expression restricted to erythroid, muscle and 
Table 4 Haplotype frequencies for crossbred animals and Angus, Charolais and Limousin breeds

\begin{tabular}{lccccc}
\hline **HAP ID & Haplotype & $\begin{array}{c}\text { Crossbred } \\
\text { animals } \\
(\mathbf{n}=141)\end{array}$ & $\begin{array}{c}\text { ANG } \\
(\mathbf{n}=\mathbf{1 5})\end{array}$ & $\begin{array}{c}\text { CHAR } \\
(\mathbf{n}=\mathbf{1 5})\end{array}$ & $\begin{array}{c}\text { LIM } \\
(\mathbf{n}=\mathbf{1 5})\end{array}$ \\
\hline 1 & CTGGCCA & 0.123 & 0.100 & 0.167 & - \\
2 & CTGCCCA & 0.344 & 0.266 & 0.333 & 0.500 \\
3 & TCACTCA & 0.185 & 0.066 & 0.233 & 0.300 \\
4 & CCGCCCA & 0.177 & 0.534 & 0.200 & 0.133 \\
\hline
\end{tabular}

**Only haplotypes with a frequency greater than $10 \%$ of population are presented

ANG: Aberdeen Angus, CHAR: Charolais, LIM: Limousin

neural tissue in human, but despite these limitations, tissue-specific isoforms with multiple transcripts are generated by alternative splicing under the control of several tissue-specific promoters [33,39].

Single nucleotide polymorphisms (SNPs) within regulatory regions can regulate the level and/or timing of gene transcription [26-28]. Evolutionary mutations arising in a promoter can have variable effects depending on the rSNP location relative to TFBS, start codons, transcription start sites etc, and the intracellular molecular environment. In some cases, a SNP may eliminate the natural binding site of a tissue-specific transcription factor or create a new binding site [28]. Therefore, functional rSNPs in TFBS may lead to differences in gene expression [28] with significant potential to increase phenotypic diversity. In this study, several ANK1 rSNPs were associated with meat quality traits. After correction for multiple testing, two of the SNP associations remained significant. These were the association between rSNP1 and tenderness score and the association between rSNP4 and texture values. While it is possible that these are marker SNPs rather than causative, of interest was that the rSNPs were found within well supported putative transcription factor binding motifs. For instance, presence of the minor $\mathrm{T}$ allele of $\mathrm{rSNP} 1$ created a glucocorticoid receptor (GR) motif and

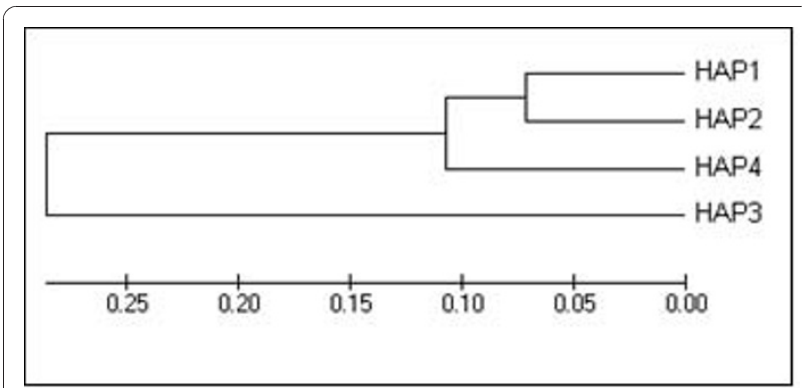

Figure 5 Neighbour joining tree of four major ANK1 promoter haplotypes in crossbred cattle. HAP1 (CTGGCCA) and HAP2 (CTGCCCA) were the most closely related haplotypes, followed by HAP4 (CCGCCCA). HAP3 (TCACTCA) was the most distant. presence of the C allele of rSNP4 created a Sp1 motif. Glucocorticoids are steroid hormones which regulate a variety of biological processes and can influence many functions of a cell [43]. The GR functions as a hormone-induced transcription factor which has been shown to regulate (either stimulate or repress) gene expression [43-45]. The presence of allele C of rSNP4 led to the creation of a Sp1 motif. Sp1 has been shown to bind to a consensus sequence of the leptin gene promoter and mutations in this region abolished the binding and reduce promoter activity in rat [46]. Adamowicz and co-workers [47] also reported that a mutation in the Sp1 binding site of the bovine leptin gene affects its expression level. The presence of a $G$ allele of this SNP (rSNP4) created a binding site for the zinc finger nuclear protein, YY1 (Yin Yang 1), also known as NFE1, UCRBP or CF1, which is known to have fundamental roles in repressing and activating a diverse group of promoters; it not only initiates transcription but also activates or represses it $[48,49]$. YY1 is also shown to repress muscle specific expression of sarcomeric alphaactin and c-myc genes [49]. Walowitz and co-workers also reported that calpains and the $26 \mathrm{~S}$ proteasome are involved in YY1 stability in rat muscle indicating that myogenic transcription may be inactivated by developmentally regulated proteolysis to promote muscle development. While it was not the aim of the present study, further functional studies would be valuable to assess the role of these TFBS, in modulating the expression of muscular transcripts of the bovine ankyrin 1 gene.

Few studies have examined variation in $A N K 1$ in relation to muscle biology. However, Wimmers et al. [20] examined one SNP in the 3' UTR region of the porcine homolog. They have reported that this SNP in the 3' UTR of porcine $A N K 1$ showed associations with shear force and IMF content, as well as several traits related to water-binding capacity in muscle [20], in several pig breeds.

In the present study, several of these rSNP were linked, therefore association analysis with individual haplotypes was also carried out. HAP4 was significantly associated with measures of tenderness. Sensory tenderness and firmness scores were improved in animals with HAP4 genotypes (approximately 5-10\%), as was shear force (10-20\%). These effect sizes suggest that the influence on tenderness is quantitative rather than that of a major gene [50]. However, this effect may be important to perceived tenderness. Recent research has shown that beef with shear force values higher than $52.68 \mathrm{~N}$ can be reliably classified as 'tough' by sensory panellists and beef with shear force values lower than $42.87 \mathrm{~N}$ can be reliably classified as 'tender' [51]. The observed genotypes and haplotypes at these promoter SNPs can thus potentially discern 'tender' from 'intermediate' to tough' 
Table 5 Significant associations $(P<0.05)$ and tendencies towards association $(P<0.1)$ between rSNP genotypes and meat quality traits and least squares means for each genotype

\begin{tabular}{|c|c|c|c|c|c|}
\hline \multirow[t]{2}{*}{ SNPs } & \multirow[t]{2}{*}{ Traits } & \multirow[t]{2}{*}{$P$-value } & \multicolumn{3}{|c|}{ Least squares mean per genotype } \\
\hline & & & $1 / 1$ & $1 / 2$ & $2 / 2$ \\
\hline & & & $\mathrm{n}=79$ & $n=55$ & $n=7$ \\
\hline \multirow[t]{9}{*}{ rSNP1 } & Tenderness-SM & 0.0002 & $5.38 \pm 0.14^{\mathrm{a}}$ & $4.77 \pm 0.14^{b}$ & $4.93 \pm 0.36^{\mathrm{ab}}$ \\
\hline & Shear force-SM & 0.0258 & $52.05 \pm 1.75^{\mathrm{a}}$ & $56.94 \pm 1.75^{b}$ & $55.13 \pm 4.41^{\mathrm{ab}}$ \\
\hline & Shear force- $L T L$ & 0.0336 & $44.38 \pm 2.92^{\mathrm{a}}$ & $52.00 \pm 2.92^{\mathrm{b}}$ & $50.20 \pm 6.78^{\mathrm{ab}}$ \\
\hline & Firmness-SM & 0.0628 & $5.52 \pm 0.09^{a}$ & $5.74 \pm 0.09^{b}$ & $5.59 \pm 0.22^{\mathrm{ab}}$ \\
\hline & Texture-SM & 0.0015 & $3.33 \pm 0.09^{a}$ & $3.67 \pm 0.09^{b}$ & $3.80 \pm 0.23^{\mathrm{ab}}$ \\
\hline & Texture-LTL & 0.0152 & $3.10 \pm 0.11^{\mathrm{a}}$ & $3.42 \pm 0.11^{b}$ & $3.01 \pm 0.26^{\mathrm{ab}}$ \\
\hline & Juiciness-SM & 0.0713 & $4.84 \pm 0.14$ & $4.50 \pm 0.14$ & $4.69 \pm 0.36$ \\
\hline & Juiciness-LTL & 0.0970 & $5.33 \pm 0.15$ & $5.09 \pm 0.15$ & $4.72 \pm 0.35$ \\
\hline & & & $\mathrm{n}=27$ & $\mathrm{n}=69$ & $\mathrm{n}=45$ \\
\hline \multirow[t]{3}{*}{ pSNP2 } & Texture-SM & 0.0996 & $3.60 \pm 0.13$ & $3.57 \pm 0.09$ & $3.34 \pm 0.11$ \\
\hline & Texture-LTL & 0.0827 & $3.12 \pm 0.15$ & $3.38 \pm 0.11$ & $3.14 \pm 0.13$ \\
\hline & & & $n=7$ & $\mathrm{n}=50$ & $\mathrm{n}=84$ \\
\hline \multirow[t]{6}{*}{ rSNP3 } & Tenderness-SM & 0.0460 & $5.19 \pm 0.37^{\mathrm{ab}}$ & $4.87 \pm 0.15^{a}$ & $5.27 \pm 0.15^{b}$ \\
\hline & Tenderness-LTL & 0.0493 & $5.60 \pm 0.37^{\mathrm{ab}}$ & $5.20 \pm 0.16^{a}$ & $5.63 \pm 0.16^{b}$ \\
\hline & Shear force- $L T L$ & 0.0051 & $50.67 \pm 6.63^{\mathrm{ab}}$ & $52.88 \pm 2.89^{a}$ & $43.06 \pm 2.94^{b}$ \\
\hline & Texture-LTL & 0.0021 & $2.88 \pm 0.26^{\mathrm{a}}$ & $3.46 \pm 0.11^{b}$ & $3.06 \pm 0.26^{\mathrm{ab}}$ \\
\hline & Flavour-SM & 0.0496 & $3.94 \pm 0.13$ & $3.66 \pm 0.05$ & $3.78 \pm 0.05$ \\
\hline & & & $n=136$ & $n=30$ & $n=5$ \\
\hline \multirow[t]{4}{*}{ rSNP4 } & Texture-SM & 0.0006 & $3.46 \pm 0.08^{\mathrm{a}}$ & $3.74 \pm 0.11^{b}$ & $2.81 \pm 0.24^{c}$ \\
\hline & Firmness-SM & 0.0753 & $5.60 \pm 0.08$ & $5.76 \pm 0.11$ & $5.25 \pm 0.23$ \\
\hline & Firmness-LTL & 0.0479 & $5.18 \pm 0.09$ & $5.38 \pm 0.13$ & $5.78 \pm 0.27$ \\
\hline & & & $\mathrm{n}=79$ & $n=56$ & $n=6$ \\
\hline \multirow[t]{5}{*}{ pSNP5 } & Tenderness-SM & 0.0037 & $5.34 \pm 0.14^{a}$ & $4.83 \pm 0.14^{b}$ & $5.23 \pm 0.40^{\mathrm{ab}}$ \\
\hline & Shear force-SM & 0.0084 & $51.54 \pm 1.76^{\mathrm{a}}$ & $57.13 \pm 1.71^{b}$ & $54.78 \pm 4.84^{\mathrm{ab}}$ \\
\hline & Shear force-LTL & 0.0038 & $43.07 \pm 2.92^{\mathrm{a}}$ & $52.49 \pm 2.82^{b}$ & $53.77 \pm 7.25^{\mathrm{ab}}$ \\
\hline & Texture-SM & 0.0279 & $3.37 \pm 0.09^{a}$ & $3.63 \pm 0.09^{b}$ & $3.61 \pm 0.27^{\mathrm{ab}}$ \\
\hline & Texture-LTL & 0.0044 & $3.09 \pm 0.11^{\mathrm{a}}$ & $3.43 \pm 0.11^{b}$ & $2.78 \pm 0.28^{\mathrm{ab}}$ \\
\hline
\end{tabular}

Significant associations are in bold and associations remaining significant after Bonferroni correction are underlined (Bonferroni-adjusted $P$-value $=0.0014)$. Least squares means with different superscripts had significant Tukey-Kramer contrasts. Genotype categories $(1 / 1,1 / 2,2 / 2)$ relate to the alternate alleles designated in Table 1-2. n: number of samples with each rSNP genotypes.

LTL: M. longissimus thoracis et lumborum muscle; SM: M. semimembranosus muscle

beef. The findings reported here may be significant as there are to date, few markers for tenderness that have been widely confirmed and are in commercial use e.g. SNP in calpain and calpastatin gene regions [52-54] and expression level of DNAJA1 $[55,56]$.

This haplotype (HAP4) was, however, associated with lower scores for texture. This means that selection for improved tenderness may result in a disimprovement in texture. However, it should be noted that sensory texture profile is not as well correlated with sensory tenderness as is Warner Bratzler shear force [57]. Low values of texture can be scored for meat that is too soft and mushy or too firm and unyielding. In contrast, low scores of tenderness and firmness are clearer in their meaning to sensory panellists (tougher and less firm respectively). Additionally, we also observed that homozygous HAP1 individuals also had reduced texture scores in SM muscle compared to individuals with no copy of this haplotype. This association remained significant even after a stringent Bonferroni correction $(P=0.0012)$, suggesting a possible role in influencing bovine muscle texture. Homozygous individuals with this haplotype also had increased firmness scores in LTL muscle.

Post-mortem tenderisation is influenced by enzymatic degradation of myofibrillar and associated cytoskeletal proteins. These proteins function to maintain myofibrillar integrity and it is known that the calpain system, in particular calpain 1, is responsible for proteolysis of these proteins $[10,12,13,15]$. The calpain family of $\mathrm{Ca}^{2+}$-dependent proteases are thus key proteins in the regulation of tenderness [58-60]. Proteins which are reported to be proteolysed by calpains can be classified as kinases/phosphatases, 
Table 6 Significant associations (P-value $<0.05$ ) and tendencies towards association (P-value $<0.1)$ for the most abundant ANK1 gene promoter haplotypes with meat quality traits and least squares means for haplotype copy number

\begin{tabular}{|c|c|c|c|c|c|}
\hline \multirow[t]{2}{*}{ HAP ID } & \multirow[t]{2}{*}{ Trait } & \multirow[t]{2}{*}{$P$-value } & \multicolumn{3}{|c|}{ Estimated trait mean per haplotype copy } \\
\hline & & & 0 & 1 & 2 \\
\hline \multirow[t]{5}{*}{ HAP1 } & & & $N=109$ & $N=27$ & $N=5$ \\
\hline & Texture-SM & 0.0012 & $3.48 \pm 0.08^{\mathrm{a}}$ & $3.74 \pm 0.12^{\mathrm{a}}$ & $2.82 \pm 0.24^{b}$ \\
\hline & Texture-LTL & $\overline{0.0974}$ & $3.18 \pm 0.10$ & $3.40 \pm 0.15$ & $3.74 \pm 0.30$ \\
\hline & Firmness-SM & 0.0917 & $5.61 \pm 0.08$ & $5.76 \pm 0.11$ & $5.25 \pm 0.23$ \\
\hline & Firmness-LTL & 0.0176 & $5.18 \pm 0.09$ & $5.45 \pm 0.13$ & $5.79 \pm 0.26$ \\
\hline \multirow[t]{6}{*}{ HAP2 } & & & $N=61$ & $N=67$ & $N=13$ \\
\hline & Texture-SM & 0.0125 & $3.66 \pm 0.09^{a}$ & $3.39 \pm 0.09^{b}$ & $3.36 \pm 0.19^{\mathrm{ab}}$ \\
\hline & Texture-LTL & 0.0861 & $3.33 \pm 0.11$ & $3.21 \pm 0.11$ & $2.82 \pm 0.23$ \\
\hline & Juiciness-SM & 0.0918 & $4.51 \pm 0.14$ & $4.83 \pm 0.14$ & $4.78 \pm 0.29$ \\
\hline & IMF-SM & 0.0275 & $1.06 \pm 0.16^{a}$ & $1.10 \pm 0.16^{a}$ & $1.95 \pm 0.33^{b}$ \\
\hline & IMF-LTL & 0.0276 & $2.06 \pm 0.24^{a}$ & $2.41 \pm 0.24^{\mathrm{ab}}$ & $3.30 \pm 0.48^{b}$ \\
\hline \multirow[t]{4}{*}{ HAP3 } & & & $N=92$ & $N=43$ & $N=6$ \\
\hline & Tenderness-SM & 0.0317 & $5.26 \pm 0.14^{\mathrm{a}}$ & $4.82 \pm 0.16^{b}$ & $5.20 \pm 0.41^{\mathrm{ab}}$ \\
\hline & Shear force- $L T L$ & 0.0727 & $45.19 \pm 2.90$ & $51.83 \pm 3.11$ & $54.42 \pm 7.44$ \\
\hline & Texture-LTL & 0.0070 & $3.12 \pm 0.11^{\mathrm{a}}$ & $3.46 \pm 0.12^{b}$ & $2.80 \pm 0.29^{\mathrm{ab}}$ \\
\hline \multirow[t]{5}{*}{ HAP4 } & & & $N=100$ & $N=35$ & $N=6$ \\
\hline & Tenderness-LTL & 0.0195 & $5.30 \pm 0.14^{\mathrm{a}}$ & $5.82 \pm 0.20^{b}$ & $5.65 \pm 0.42^{\mathrm{ab}}$ \\
\hline & Shear force- $L T L$ & 0.0188 & $50.12 \pm 2.61^{\mathrm{a}}$ & $41.99 \pm 3.57^{b}$ & $36.92 \pm 7.68^{a b}$ \\
\hline & Texture-LTL & 0.0146 & $3.34 \pm 0.10^{a}$ & $2.97 \pm 0.14^{b}$ & $2.99 \pm 0.30^{\mathrm{ab}}$ \\
\hline & Firmness-LTL & 0.0143 & $5.34 \pm 0.09^{a}$ & $5.00 \pm 0.12^{b}$ & $5.02 \pm 0.27^{\mathrm{ab}}$ \\
\hline
\end{tabular}

Significant associations are in bold and associations remaining significant after Bonferroni correction are underlined (Bonferroni-adjusted $P$-value $=0.0014$ ). Least squares means with different superscripts had significant Tukey-Kramer contrasts. N (Number of samples with each haplotype copies)

LTL: M. longissimus thoracis et lumborum muscle; SM: M. semimembranosus muscle

membrane associated proteins, some transcription factors and cytoskeletal proteins which include desmin, gelsolin, myosin, nebulin, spectrins, titin, tropomyosin -for review see [61]. Ankyrin is one of the cytoskeletal proteins proteolysed by members of the calpain family $[7,16,61,62]$. Since ankyrin has functions in maintaining the structural integrity of, and linkages among myofibrils, the degradation of ankyrin could cause further softening of myofibrils and thus, tenderization. The relationship between tenderness (sensory and shear force) and HAP4 or rSNP1, rSNP3 of the bovine ANK1 promoter, may indicate that this haplotype and/or these rSNP might alter the expression of cytoskeletal protein ankyrin 1 in muscle and thus the extent of post-mortem proteolysis by calpains.

An association with IMF content (\%) was observed for HAP2 in both muscles. This was supported by sensory juiciness score, which is an indirect sensory measure of intramuscular fat content [31,32], in that HAP2 showed a tendency towards increased juiciness in SM muscle. Intramuscular fat has been shown to contribute 10 $15 \%$ of the variance in palatability of beef [63]. These results suggest that HAP2 may have potential in selection for IMF content. It is curious that HAP2 was associated with IMF but only differs from HAP4 and HAP1 by a single SNP in each case (rSNP2 and rSNP4, respectively). Neither rSNP2 nor rSNP4 are associated with IMF alone. This suggests that the relationship between HAP2 and this trait may be via linkage to nearby functional SNP. In fact, a number of QTL for marbling and fat thickness have been identified on this chromosome in a mapping population of Bos indicus $\times$ Bos taurus (including Hereford, Angus and Charolais) cattle [18,19]. More recently, 3 QTL for marbling and 2 QTL for fat thickness have been identified on chromosome 27 in commercial Angus cattle [19]. While ANK1 is not located within any of these QTL, its proximity supports the hypothesis that it is a candidate gene for these traits.

Many improvements in meat quality can be achieved by optimising systems management in animal production and meat processing [64-66]. However, in addition to environmental and processing influences on meat quality, there are certainly biological factors which affect the quality of meat [67-70]. The identification of genomic regions influencing economically important traits, in particular tenderness and intramuscular fat, has been made possible due to polymorphic markers and linkage maps in cattle. However, just a few genes have been located within these QTL and found to be influencing 
these traits. In this study we have found that polymorphisms (SNPs and haplotypes) of the ankyrin 1 gene are in association with these important meat quality traits. This is the first time such associations have been identified, therefore it will be important to confirm these findings in independent populations [71].

\section{Conclusions}

In this report, we have shown a new transcript variant of the bovine ankyrin 1 gene in muscle. We have identified seven novel SNPs in the promoter region of bovine ANK1 and several of these SNPs and inferred haplotypes were associated with meat quality traits, in particular meat tenderness and intramuscular fat. Of interest was that some of these promoter SNPs were also found within well supported putative transcription factor binding motifs, supporting the assumption that SNPs in transcription factor binding sites may lead to differences in gene expression with significant potential to increase phenotypic diversity. This gene region is a potential target for gene-assisted selection to improve meat quality. However, validation of these associations in independent populations is key before their practical application. Additional future studies could focus on expression analysis to demonstrate the functional role of the identified promoter variation.

\section{Methods}

Identification of the transcription start site of the bovine ankyrin 1 gene

Most of the sequences available in the NCBI and Ensembl databases shared little to no consensus concerning the size of the 5' UTR region of the ankyrin 1 gene or of a transcription start site (TSS). Hence, the TSS of the muscle ANK1 gene was determined by 5' RACE-PCR.

\section{Tissue samples and RNA extraction}

$M$. longissimus thoracis et lumborum (striploin) samples were taken from 3 slaughter-weight commercial beef animals within one hour post slaughter in an EUlicensed abattoir. Tissue samples ( $2 \mathrm{~g}$ each) were homogenised and preserved in $10 \mathrm{ml}$ RNAlater (Ambion, Inc. Austin, TX). Total RNA was extracted from $50 \mathrm{mg}$ of the preserved bovine muscle tissue using TRI Reagent ${ }^{\circ}$ (Molecular Research Centre, Inc. USA), following the supplier's protocol. The RNA was then dissolved in $40 \mu \mathrm{l}$ of $0.1 \%$ DEPC treated water and then subjected to deoxyribonuclease I (DNase I) treatment (QIAGEN Ltd., West Sussex, UK). Purification of RNA was carried out using the universal phenol-chloroform method. The RNA pellet was finally resolvated in $40 \mu \mathrm{l}$ of nucleasefree water. Quality and quantity of the total RNA was assessed on a $1.2 \%$ agarose gel and on a NanoDrop ${ }^{\circ}$ ND-1000 Spectrophotometer (Thermo Fisher Scientific
Inc. MA, USA), respectively. Samples with an A260/280 ratio $1.7 \leq 2.0$ were selected for further examination. RNA was aliquoted and stored at $-80^{\circ} \mathrm{C}$ prior to cDNA synthesis.

$5^{\prime}$ end CDNA synthesis and amplification of the $5^{\prime}$ end CDNA region

5' end cDNA was synthesized from $2.5 \mu \mathrm{g}$ of total RNA using a GeneRacer ${ }^{\text {Tw }}$ Kit (Invitrogen Corp., San Diego, CA, USA) according to supplier's protocols. 5' cDNA was synthesized from modified RNA using Superscrip$\mathrm{t}^{\mathrm{m}} \mathrm{III}$ first-strand synthesis system using oligo $(\mathrm{dT})_{20}$ primer with $1.0 \mu \mathrm{l}$ of total RNA in a final reaction volume of $20 \mu \mathrm{l}$ using the Superscript ${ }^{\text {tix }}$ III First-strand synthesis system for reverse transcriptase-polymerase chain reaction (RT-PCR) (Invitrogen Corp.). GeneRacer Oligo dT primer with oligo $(\mathrm{dT})_{24}$ with the anchor sequence was used to reverse transcribe the mRNA. A gene specific primer (ANK1E2; reverse: 5'-CTG CCC TCA GAA AGC TGG TA-3', btau_4.0; chr27: 39,084,536 39,084,476, minus strand) [GenBank: NC_007328.3] was designed based on the ANK1 bovine genomic DNA sequence to amplify different sizes of cDNA fragment from the total RNA extracted. The single-stranded cDNAs were amplified using the 5' adaptor primer (Forward 5'-CGA CTG GAG CAC GAG GAC ACT GA-3') (Invitrogen Corp.). High fidelity Supermix (Invitrogen Corp.) was used for the PCR in a total volume of $25 \mathrm{ml}$ and the conditions were as follows: initial denaturation at $94^{\circ} \mathrm{C}$ for $2 \mathrm{~min}$ followed by 40 cycles of denaturation $\left(94^{\circ} \mathrm{C} 30 \mathrm{~s}\right)$, annealing $\left(56^{\circ} \mathrm{C}\right.$ for $\left.30 \mathrm{~s}\right)$ and extension $\left(68^{\circ} \mathrm{C}\right.$ for $\left.30 \mathrm{~s}\right)$ with a final extension at $72^{\circ} \mathrm{C}$ for $5 \mathrm{~min}$. PCR products were visualized on a $1.2 \%$ agarose gel.

Cloning of the extracted 5'end RACE cDNA fragments was achieved by using the TOPO-TA cloning kit (Invitrogen Corp.). cDNAs were ligated into $\mathrm{pCR}^{\circ} 4$-TOPO plasmid followed by transformation into TOP10 Escherichia coli cells (Invitrogen Corp.). Single colonies were transferred to cell culture plate containing $10 \mathrm{ml} \mathrm{LB}$ medium supplemented with $50 \mathrm{mg} / \mathrm{ml}$ ampicillin (SigmaAldrich Corp., USA) and grown overnight at $37^{\circ} \mathrm{C}, 140 \mathrm{r}$. p.m. Small aliquots of the overnight cell cultures of recovered colonies were plated at limiting dilution in 15 $\mathrm{ml} \mathrm{LB}$ containing $100 \mathrm{mg} / \mathrm{ml}$ ampicillin. Plasmid DNA was purified using the GenElute "' Plasmid Purification kit (Sigma-Aldrich Corp.) according to supplier's protocol.

$30 \mu \mathrm{l}$ of PCR product was cleaned up using Gen Elute ${ }^{\mathrm{Tw}} \mathrm{PCR}$ clean-up kit (Sigma-Aldrich Corp.) following the manufacturer's protocol. The quality and quantity of the purified PCR product was assessed on a 1.2\% agarose gel and on a NanoDrop ND-1000 Spectrophotometer (Thermo Fisher Scientific Inc. MA, USA). Randomly selected 12 plasmid DNAs (200 $\mathrm{ng}$ ) were sequenced in both reverse and forward directions to confirm constructs by Eurofins, MWG-Biotech (Edelsberg, Germany). 


\section{Animals, DNA preparation and Phenotype Animals and DNA preparation}

Blood samples of unrelated purebred Aberdeen Angus, Charolais and Limousin bulls ( $\mathrm{n}=15$ per breed) were taken to determine the base-line level of DNA polymorphisms in purebred beef breeds. M. longissimus thoracis et lumborum (LTL) and M. semimembranosus (SM) tissue samples of commercial crossbred cattle ( $\mathrm{n}=$ 141; the major contributing breeds were Charolais, Hereford, Limousin, Friesian, Holstein-Friesian and Simmental) were collected from an EU licensed abattoir and meat quality measured for a number of traits as described previously [72]. A total of seven meat quality traits for each muscle type (SM and LTL) were examined, two relating to technological measure of meat quality i.e. intramuscular fat content and shear force; and five relating to sensory traits i.e. texture, tenderness, flavour, juiciness and firmness. DNA was extracted from muscle and blood using the DNeasy ${ }^{\odot}$ blood and tissue kit (QIAGEN Ltd.).

\section{Phenotype}

The meat quality data has been analysed and previously published in detail $[70,72,73]$. Compositional analysis was carried out on meat frozen at 14 days post-mortem and IMF \% levels assessed according to a recognised protocol [74]. The Warner-Bratzler shear force measurement is the most widely accepted instrumental technique to determine the tenderness of meat. WarnerBratzler shear force values represent the amount of force required to shear a $2.54 \mathrm{~cm}$ core of a cooked and tempered meat sample [75], in this study they are reported in Newtons $(\mathrm{N})$. The less force (lower $\mathrm{N}$ ) required to shear through the meat sample, the more tender the product. Tenderness, texture, flavour and firmness measures were carried out by sensory analysis. The panellists graded tenderness, texture and firmness on a scale of 1-8, as follows: (tenderness $1=$ extremely tough, 8 = extremely tender; texture: $1=$ very poor, $8=$ extremely good; firmness: 1 = extremely mushy, $8=$ extremely firm). Panellists graded flavour and juiciness in a scale of 1-6, as follows: flavour: $1=$ very poor, $6=$ extremely good; juiciness: 1 = very dry, 6 = extremely juicy. Studies have shown that there is a fairly high, but not perfect, inverse correlation (-0.72) between WarnerBratzler shear force measurements and sensory tenderness ratings [51]. Samples producing shear force values of greater than 52.68 Newtons were considered 'tough' by sensory panellists [51].

\section{Polymorphism identification and validation}

Initially the $1.11 \mathrm{~kb}$ promoter region of the ankyrin 1 gene was resequenced in all purebred and crossbred animals. Subsequently, three of the SNPs were validated using custom Taqman SNP genotyping assays.

\section{DNA sequencing}

In order to amplify $1.11 \mathrm{~kb}$ of the bovine $A N K 1$ promoter two sets of overlapping primers (fragment 1, $702 \mathrm{bp}$ : forward: 5'-CTG AGT GAC TGA GCA CTG TAA TGA-3', reverse: 5'-GGT GTT TTT GCT TCT CCA GC-3' btau_4.0 chr27: 39,125,655 to 39,124,954; fragment 2, 711 bp: forward: 5'-AGC TGC TGT GGG AAC AGA GT-3', reverse: 5'- GTT CCC CAA GTG AAG GTA GC-3' btau_4.0 chr27: $39,125,196$ to $39,124,486$, minus strand) were designed to detect genetic polymorphisms based on published sequence data [GenBank: NW_001494427.2]. 100 ng of genomic DNA was used to generate PCR products in the presence of 200 pM of both forward and reverse primers. PCR amplifications were performed with $2 \mu \mathrm{l}$ of the genomic DNA template in a $50 \mu$ final reaction volume. The PCR reaction consisted of $10 \mu \mathrm{l} 5 \times$ PCR buffer, $3 \mu \mathrm{l} 25 \mathrm{mM} \mathrm{MgCl} 2,1 \mu \mathrm{l}$ dNTPmix (10 mM of each), $2 \mu \mathrm{l}$ Primer mix $(0.2 \mu \mathrm{M}$ each of the forward and reverse primers), $0.4 \mu \mathrm{l} \mathrm{GoTaq}{ }^{\oplus}$ DNA Polymerase (100 U) (PGEM, Promega Corp. USA). The cycling conditions used were as follows: initial denaturation at $94^{\circ} \mathrm{C}$ for $2 \mathrm{~min}$ followed by 35 cycles of $94^{\circ} \mathrm{C}$ for $45 \mathrm{sec}, 56$ and $57^{\circ} \mathrm{C}$ (respectively for each primer pair) for $45 \mathrm{sec}$ and $72^{\circ} \mathrm{C}$ for $1 \mathrm{~min} 20 \mathrm{sec}$ for followed by a final extension of $72^{\circ} \mathrm{C}$ for $10 \mathrm{~min}$ for all fragments. All PCR products were analysed by agarose gel electrophoresis (1.2\%) and ethidium bromide staining and visualised using the Epi Chemi II Darkroom (UVP, Upland, CA) equipped with the image analysis program LabWorks. PCR products were purified prior to sequencing using the QIAGEN PCR purification kit (QIAGEN Ltd.). Sequencing of the purified PCR product was carried out by Eurofins, MWG-Biotech. Sequences were aligned and the data analyzed using MEGA ${ }^{\oplus}$ (Molecular Evolutionary Genetic Analysis) v 4.0 software [76] MEGA4.

\section{SNP validation}

Two closely linked SNPs $\left(r^{2}=1\right)(\mathrm{rSNP} 1$ and $\mathrm{rSNP} 5 \mathrm{~s})$ and another SNP (rSNP2) were selected and re-genotyped for validation purposes using Custom TaqMan ${ }^{\circledR}$ SNP Genotyping Assays (Applied Biosystems, Foster City, CA, USA), in all commercial crossbred and purebred samples. Primers and probes for the assay were designed using Primer Express and were synthesized by Applied Biosystems. Each $10 \mu \mathrm{l}$ PCR reaction consisted of $5 \mu \mathrm{l}$ mastermix (TaqMan ${ }^{\curvearrowleft}$ genotyping mastermix, Applied Biosystems), $0.25 \mu \mathrm{l}$ genotyping assay, $2.75 \mu \mathrm{l} \mathrm{dH} 2 \mathrm{O}$ and $2 \mu \mathrm{l}$ of DNA (10 ng/ $\mu \mathrm{l})$. The PCR thermal cycling was as follows: initial denaturing at $95^{\circ} \mathrm{C}$ for $10 \mathrm{~min} ; 40$ cycles of $95^{\circ} \mathrm{C}$ for $15 \mathrm{~s}$ and $60^{\circ} \mathrm{C}$ for $1 \mathrm{~min}$. Thermal cycling was performed using an $\mathrm{ABI} \mathrm{PRISM}^{\odot} 7500$.

\section{Transcriptional effects of regulatory SNPs in the bovine ANK1 promoter region}

To identify SNPs that affect promoter elements, including putative transcription factor binding sites of interest, 
$1.11 \mathrm{~kb}$ upstream of the ANK1 translation start site were screened for the presence of putative selective transcription factor binding sites in silico using three prediction tools (TESS; http://www.cbil.upenn.edu/tess), TRANSFAC http://www.biobase-international.com/index.php? id=transfac and MatInspector http://www.genomatix.de/ en/index.html. Particular attention was paid to binding sites already proven to be of significance in regulating the muscle specific binding sites of bovine and other common binding sites in mouse and human.

\section{Statistical methods}

\section{Allele, Genotype, and Haplotype Frequencies, LD}

Estimation of allele frequencies and departures from Hardy-Weinberg equilibrium (HWE) were carried out using the population genetic data analysis software Haploview [77]. Linkage disequilibrium measures were also estimated using Haploview. Following haplotype inference, the ELB algorithm was used to assign the most likely haplotype combination to an individual as implemented in the Arlequin program [78].

\section{Association analysis}

Evaluation of association between the seven SNPs and values of meat quality traits for each individual SNP in the crossbred population $(\mathrm{n}=141)$ were carried out using the least squares method of the GLM (General Linear Model) procedure in SAS (Version 9.1, SAS Inst., Inc., Cary, NC, 2002-2003). A number of covariates (sex, age, carcass weight, slaughter period, and slaughter factory) were included in the model to control for potentially confounding factors. Five ANK1 regulatory SNPs with MAF $>0.1$ were tested for associations with meat quality traits. Where significant associations were identified, mean trait values for each genotype were contrasted using the Tukey-Kramer procedure in SAS. In order to evaluate the association of individual alleles with meat quality, the four most common haplotypes of the crossbred population (frequencies of more than $10 \%$ ) were also tested in separate GLM models including the same covariates as the single SNP analyses. Each analysis tested for a difference in least squares means of meat quality traits where 0,1 or 2 copies of each haplotype were present. Tukey-Kramer analysis was also carried out for significant associations. A Bonferroniadjusted $P$-value was calculated for individual SNP and haplotype analyses.

\section{Acknowledgements}

The authors acknowledge the Irish Department of Agriculture, Fisheries and Food, through the Food Institutional Research Measure for funding, and also wish to thank Ms Paula Reid for assistance with statistical analysis. The authors acknowledge the Irish Cattle Breeding Federation for supplying blood samples.

\section{Author details}

${ }^{1}$ Teagasc, Food Research Centre, Ashtown, Dublin 15, Ireland. ${ }^{2}$ University College Dublin (UCD), School of Agriculture, Food Science \& Veterinary Medicine, Dublin 4, Ireland.

\section{Authors' contributions}

OA carried out the laboratory work, population genetic data analysis, participated in data interpretation and prepared the first draft of the manuscript. TS, RMH and AMM designed and coordinated the study. RMH and TS participated in data interpretation and drafting of the manuscript. All authors agreed with the final manuscript.

Received: 19 August 2010 Accepted: 15 December 2010

Published: 15 December 2010

\section{References}

1. Nelson WJ, Lazarides E: Goblin (ankyrin) in striated muscle: identification of the potential membrane receptor for erythroid spectrin in muscle cells. Proc Natl Acad Sci USA 1984, 81:3292-3296.

2. Gagelin C, Constantin B, Deprette C, Ludosky MA, Recouvreur M, Cartaud J, Cognard C, Raymond G, Kordeli E: Identification of Ank(G107), a musclespecific ankyrin-G isoform. J Biol Chem 2002, 277:12978-12987.

3. Porter NC, Resneck WG, O'Neill A, Van Rossum DB, Stone MR, Bloch RJ: Association of small ankyrin 1 with the sarcoplasmic reticulum. Molecular membrane biology 2005, 22:421-432.

4. Tuvia $S$, Buhusi $M$, Davis $L$, Reedy $M$, Bennett $V$ : Ankyrin-B is required for intracellular sorting of structurally diverse $\mathrm{Ca} 2+$ homeostasis proteins. The Journal of cell biology 1999, 147:995-1008.

5. Bagnato P, Barone V, Giacomello E, Rossi D, Sorrentino V: Binding of an ankyrin-1 isoform to obscurin suggests a molecular link between the sarcoplasmic reticulum and myofibrils in striated muscles. The Journal of cell biology 2003, 160:245-253.

6. Rubtsov AM, Lopina OD: Ankyrins. FEBS letters 2000, 482:1-5.

7. Harada K, Fukuda S, Kunimoto M, Yoshida K: Distribution of ankyrin isoforms and their proteolysis after ischemia and reperfusion in rat brain. J Neurochem 1997, 69:371-376.

8. Boivin P, Galand C, Dhermy D: In vitro digestion of spectrin, protein 4.1 and ankyrin by erythrocyte calcium dependent neutral protease (calpain I). Int J Biochem 1990, 22:1479-1489.

9. Croall DE, DeMartino GN: Calcium-activated neutral protease (calpain) system: structure, function, and regulation. Physiol Rev 1991, 71:813-847.

10. Koohmaraie M: Biochemical Factors Regulating the Toughening Tenderization Processes of Meat. Meat Science 1996, 43:193-201.

11. Ouali A: Proteolytic and physicochemical mechanisms involved in meat texture development. Biochimie 1992, 74:251-265.

12. Ouali A, Herrera-Mendez C, Coulis G, Becila S, Boudjellal A, Aubry L, Sentandreu M: Revisiting the conversion of muscle into meat and the underlying mechanisms. Meat Science 2006, 74:44-58.

13. Sentandreu M, Coulis $G$, Ouali A: Role of muscle endopeptidases and their inhibitors in meat tenderness. Trends in Food Science \& Technology 2002, 13:400-421.

14. Koohmaraie M, Kent M, Shackelford S, Veiseth $E$, Wheeler T: Meat tenderness and muscle growth: is there any relationship? Meat Science 2002, 62:345-352.

15. Taylor RG, Koohmaraie M: Effects of postmortem storage on the ultrastructure of the endomysium and myofibrils in normal and callipyge longissimus. J Anim Sci 1998, 76:2811-2817.

16. Harada K, Sorimachi Y, Yoshida K: Proteolysis of ankyrin and $\mathrm{Na}+/ \mathrm{K}$ (+)-ATPase in postmortem rat brain: is calpain involved? Forensic Sci Int 1997, 86:77-85

17. Casas E, Shackelford SD, Keele JW, Stone RT, Kappes SM, Koohmaraie M: Quantitative trait loci affecting growth and carcass composition of cattle segregating alternate forms of myostatin. J Anim Sci 2000, 78:560-569.

18. Casas E, Shackelford SD, Keele JW, Koohmaraie M, Smith TP, Stone RT: Detection of quantitative trait loci for growth and carcass composition in cattle. J Anim Sci 2003, 81:2976-2983.

19. McClure MC, Morsci NS, Schnabel RD, Kim JW, Yao P, Rolf MM, McKay SD, Gregg SJ, Chapple RH, Northcutt SL, Taylor JF: A genome scan for 
quantitative trait loci influencing carcass, post-natal growth and reproductive traits in commercial Angus cattle. Anim Genet 2010, 41:597-607.

20. Wimmers K, Murani E, Te Pas MF, Chang KC, Davoli R, Merks JW, Henne H, Muraniova M, da Costa N, Harlizius B, et al: Associations of functional candidate genes derived from gene-expression profiles of prenatal porcine muscle tissue with meat quality and muscle deposition. Anim Genet 2007, 38:474-484.

21. Bahar B, Sweeney T: Mapping of the transcription start site (TSS) and identification of SNPs in the bovine neuropeptide Y (NPY) gene. BMC Genetics 2008, 9:91

22. Roni V, Carpio R, Wissinger B: Mapping of transcription start sites of human retina expressed genes. BMC Genomics 2007, 8:42.

23. Taylor MS, Kai C, Kawai J, Carninci P, Hayashizaki Y, Semple CA: Heterotachy in mammalian promoter evolution. PLoS Genet 2006, 2:e30.

24. Levine M, Tjian R: Transcription regulation and animal diversity. Nature 2003, 424:147-151.

25. Planas J, Serrat JM: Gene promoter evolution targets the center of the human protein interaction network. PLOS One 2010, 5:e11476.

26. Wang YH, Byrne KA, Reverter A, Harper GS, Taniguchi M, McWilliam SM Mannen H, Oyama K, Lehnert SA: Transcriptional profiling of skeletal muscle tissue from two breeds of cattle. Mammalian Genome 2005, 16:201-210.

27. Wang X, Tomso DJ, Chorley BN, Cho HY, Cheung VG, Kleeberger SR, Bell DA: Identification of polymorphic antioxidant response elements in the human genome. Hum Mol Genet 2007, 16:1188-1200.

28. Chorley BN, Wang X, Campbell MR, Pittman GS, Noureddine MA, Bell DA: Discovery and verification of functional single nucleotide polymorphisms in regulatory genomic regions: current and developing technologies. Mutation Research/Reviews in Mutation Research 2008, 659:147-157.

29. Tan Q, Christiansen L, Christensen K, Bathum L, Li S, Zhao JH, Kruse TA: Haplotype association analysis of human disease traits using genotype data of unrelated individuals. Genet Res 2005, 86:223-231.

30. Li J, Zhou Y, Elston RC: Haplotype-based quantitative trait mapping using a clustering algorithm. BMC Bioinformatics 2006, 7:258

31. Oddy VH, Harper GS, Greenwood PL, McDonagh MB: Nutritional and developmental effects on the intrinsic properties of muscles as they relate to the eating quality of beef. Australian Journal of Experimental Agriculture 2001, 41:921-942.

32. Hocquette JF, Gondret F, Baéza E, Médale F, Jurie C, Pethick DW: Intramuscular fat content in meat-producing animals: development, genetic and nutritional control, and identification of putative markers. Animal 2010, 4:303-319.

33. Gallagher PG, Tse WT, Scarpa AL, Lux SE, Forget BG: Structure and organization of the human ankyrin-1 gene. Basis for complexity of premRNA processing. J Biol Chem 1997, 272:19220-19228.

34. Mohler PJ, Bennett V: Defects in ankyrin-based cellular pathways in metazoan physiology. Front Biosci 2005, 10:2832-2840

35. Mohler PJ, Gramolini AO, Bennett V: Ankyrins. J Cell Sci 2002, 115:1565-1566

36. Boichard D, Grohs C, Bourgeois F, Cerqueira F, Faugeras R, Neau A, Rupp R, Amigues $Y$, Boscher MY, Leveziel $\mathrm{H}$ : Detection of genes influencing economic traits in three French dairy cattle breeds. Genetics Selection Evolution 2003, 35:77-101

37. Li C, Basarab J, Snelling WM, Benkel B, Kneeland J, Murdoch B, Hansen C, Moore SS: Identification and fine mapping of quantitative trait loci for backfat on bovine chromosomes 2, 5, 6, 19, 21, and 23 in a commercial line of Bos taurus. Journal of Animal Science 2004, 82:967-972.

38. Cunha SR, Mohler PJ: Cardiac ankyrins: Essential components for development and maintenance of excitable membrane domains in heart. Cardiovascular research 2006, 71:22-29.

39. Gallagher PG, Forget BG: An alternate promoter directs expression of a truncated, muscle-specific isoform of the human ankyrin 1 gene. J Biol Chem 1998, 273:1339-1348.

40. Bennett V, Baines AJ: Spectrin and ankyrin-based pathways: metazoan inventions for integrating cells into tissues. Physiol Rev 2001, 81:1353-1392

41. Das A, Base C, Dhulipala S, Dubreuil RR: Spectrin functions upstream of ankyrin in a spectrin cytoskeleton assembly pathway. The Journal of cell biology 2006, 175:325-335.
42. Zhou D, Birkenmeier CS, Williams MW, Sharp JJ, Barker JE, Bloch RJ: Small, membrane-bound, alternatively spliced forms of ankyrin 1 associated with the sarcoplasmic reticulum of mammalian skeletal muscle. The Journal of cell biology 1997, 136:621-631.

43. Geng $C D$, Vedeckis W: Steroid-responsive sequences in the human glucocorticoid receptor gene 1A promoter. Mol Endocrinol 2004 18:912-924.

44. Wadekar SA, Li D, Periyasamy S, Sanchez ER: Inhibition of heat shock transcription factor by GR. Mol Endocrinol 2001, 15:1396-1410.

45. Berg JP: Glucocorticoid-stimulated gene expression knocked out by knock-in mutation. Eur J Endocrinol 1998, 139:479-480.

46. Mason MM, He Y, Chen H, Quon MJ, Reitman M: Regulation of leptin promoter function by Sp1, C/EBP, and a novel factor. Endocrinology 1998, 139:1013-1022.

47. Adamowicz T, Flisikowski K, Starzynski R, Zwierzchowski L, Switonski M: Mutation in the Sp1 motif of the bovine leptin gene affects its expression. Mamm Genome 2006, 17:77-82.

48. Gordon S, Akopyan G, Garban H, Bonavida B: Transcription factor YY1: structure, function, and therapeutic implications in cancer biology. Oncogene 2006, 25:1125-1142.

49. Walowitz JL, Bradley ME, Chen S, Lee T: Proteolytic regulation of the zinc finger transcription factor YY1, a repressor of muscle-restricted gene expression. J Biol Chem 1998, 273:6656-6661.

50. Falconer DS, Mackay TFC: Introduction to Quantitative Genetics. Longmans Green, Harlow, Essex, UK, 41996.

51. Destefanis G, Brugiapaglia A, Barge MT, Dal Molin E: Relationship between beef consumer tenderness perception and Warner-Bratzler shear force. Meat Sci 2008, 78:153-156.

52. Barendse W: DNA markers for meat tenderness. International patent publication WO 02/064820 A1 2002.

53. White SN, Casas E, Wheeler TL, Shackelford SD, Koohmaraie M, Riley DG Chase CC, Johnson DD, Keele JW, Smith TP: A new single nucleotide polymorphism in CAPN1 extends the current tenderness marker test to include cattle of Bos indicus, Bos taurus, and crossbred descent. J Anim Sci 2005, 83:2001-2008

54. Page BT, Casas E, Heaton MP, Cullen NG, Hyndman DL, Morris CA, Crawford AM, Wheeler TL, Koohmaraie M, Keele JW, Smith TP: Evaluation of single-nucleotide polymorphisms in CAPN1 for association with meat tenderness in cattle. J Anim Sci 2002, 80:3077-3085.

55. Bernard C, Cassar-Malek I, Le Cunff M, Dubroeuca H, Renand G, Hocquette JF: New indicators of beef sensory quality revealed by expression of specific genes. J Agric Food Chem 2007, 55:5229-5237.

56. Marty A, Amigues Y, Servin B, Renand G, Leveziel H, Rocha D: Genetic variability and linkage disequilibrium patterns in the bovine DNAJA1 gene. Mol Biotechnol 2010, 44:190-197.

57. Caine WR, Aalhus JL, Best DR, Dugan MER, Jeremiah LE: Relationship of texture profile analysis and Warner-Bratzler shear force with sensory characteristics of beef rib steaks. Meat Sci 2003, 64:333-339.

58. Koohmaraie $\mathrm{M}$ : The role of $\mathrm{Ca}(2+)$-dependent proteases (calpains) in post mortem proteolysis and meat tenderness. Biochimie 1992, 74:239-245.

59. Huff Lonergan E, Zhang W, Lonergan SM: Biochemistry of postmortem muscle - lessons on mechanisms of meat tenderization. Meat Sci 2010, 86:184-195.

60. Koohmaraie M, Geesink G: Contribution of postmortem muscle biochemistry to the delivery of consistent meat quality with particular focus on the calpain system. Meat Science 2006, 74:34-43.

61. Goll DE, Thompson VF, Li H, Wei W, Cong J: The calpain system. Physiol Rev 2003, 83:731-801

62. Yoshida K, Harada K: Proteolysis of erythrocyte-type and brain-type ankyrins in rat heart after postischemic reperfusion. J Biochem 1997 122:279-285.

63. Dikeman M: Fat reduction in animals and the effect on palatability and consumer acceptance of meat products. Proceedings of 40th Annual Reciprocal Meat Conference 1987, 40:93-103.

64. Maltin C, Balcerzak D, Tilley R, Delday M: Determinants of meat quality: tenderness. Proc Nutr Soc 2003, 62:337-347.

65. Hocquette JF, Renand G, Levéziel H, Picard B, Cassar-Malek I: The potential benefits of genetics and genomics to improve beef quality - a review. Animal Science Papers and Reports 2006, 24:173-189. 
66. Hocquette JF, Richardson Rl, Prache S, Medale F, Duffy G, Scollan ND: The future trends for research on quality and safety of animal products. Italian Journal of Animal Science 2005, 4:49-72.

67. McPherron AC, Lee $\mathrm{S}$ : Double muscling in cattle due to mutations in the myostatin gene. Book Double muscling in cattle due to mutations in the myostatin gene (Editor ed.^eds.) City; 1997, 94:12457-12461.

68. Casas E, White SN, Wheeler TL, Shackelford SD, Koohmaraie M, Riley DG, Chase CC, Johnson DD, Smith TP: Effects of calpastatin and micro-calpain markers in beef cattle on tenderness traits. J Anim Sci 2006, 84:520-525.

69. Thaller G, Kuhn C, Winter A, Ewald G, Bellmann O, Wegner J, Zuhlke H, Fries R: DGAT1, a new positional and functional candidate gene for intramuscular fat deposition in cattle. Anim Genet 2003, 34:354-357.

70. Reardon W, Mullen AM, Sweeney T, Hamill RM: Association of polymorphisms in candidate genes with colour, water-holding capacity, and composition traits in bovine M. longissimus and $\mathrm{M}$. semimembranosus. Meat Sci 2010, 86:270-275.

71. Van Eenennaam AL, Li J, Thallman RM, Quaas RL, Dikeman ME, Gill CA, Franke DE, Thomas MG: Validation of commercial DNA tests for quantitative beef quality traits. J Anim Sci 2007, 85:891-900.

72. Pannier L, Sweeney T, Hamill RM, Ipek F, Stapleton PC, Mullen AM: Lack of an association between single nucleotide polymorphisms in the bovine leptin gene and intramuscular fat in Bos taurus cattle. Meat Science 2009, 81:731-737.

73. Maher SC, Mullen AM, Moloney AP, Buckley DJ, Kerry JP: Quantifying the extent of variation in the eating quality traits of the $M$. longissimus dorsi and M. semimembranosus of conventionally processed Irish beef. Meat Sci 2004, 66:351-360.

74. Bostian ML, Fish DL, Webb NB, Arey JJ: Automated methods for determination of fat and moisture in meat and poultry products: collaborative study. J Assoc Off Anal Chem 1985, 68:876-880.

75. Wheeler TL, Shackelford SD, Koohmaraie M: Beef longissimus slice shear force measurement among steak locations and institutions. J Anim Sci 2007, 85:2283-2289.

76. Tamura K, Dudley J, Nei M, Kumar S: MEGA4: Molecular Evolutionary Genetics Analysis (MEGA) software version 4.0. Mol Biol Evol 2007, 24:1596-1599.

77. Barrett JC, Fry B, Maller J, Daly MJ: Haploview: analysis and visualization of LD and haplotype maps. Bioinformatics 2005, 21:263-265.

78. Excoffier L, Laval G, Schneider S: Arlequin (version 3.0): An integrated software package for population genetics data analysis. Evolutionary Bioinformatics Online 2005, 1:47-50.

doi:10.1186/1471-2156-11-111

Cite this article as: Aslan et al.: Regulatory polymorphisms in the bovine Ankyrin 1 gene promoter are associated with tenderness and intramuscular fat content. BMC Genetics 2010 11:111.

\section{Submit your next manuscript to BioMed Central and take full advantage of:}

- Convenient online submission

- Thorough peer review

- No space constraints or color figure charges

- Immediate publication on acceptance

- Inclusion in PubMed, CAS, Scopus and Google Scholar

- Research which is freely available for redistribution

Submit your manuscript at www.biomedcentral.com/submit
Biomed Central 